\title{
Pensamiento independentista latinoamericano, derechos humanos y justicia social
}

\author{
Pablo Guadarrama González*
}

\section{RESUMEN}

La lucha por su independencia de las colonias americanas en general, es decir, en ambos hemisferios y también en la región de El Caribe debe ser apreciada en su real magnitud como un capítulo de la lucha a escala universal por los derechos humanos, la justicia social y la construcción de la modernidad.

Un elemento propulsor de esa lucha fueron innumerables sublevaciones de indígenas, esclavos, campesinos, etc., que se produjeron en toda América antes del proceso independentista, cuyas expresiones superiores fueron Bolívar, San Martín, O’Higgins, Artigas, Hidalgo, Morelos, Martí, etc., acompañados por miles de criollos, mestizos, negros, indios, en la lucha no solo por la independencia política, sino también por sus derechos y por la justicia social.

Los procesos independentistas de América Latina se vieron obligados a afrontar en las nuevas circunstancias históricas algunos requerimientos y demandas de derechos y justicia social que no eran tan evidentes y necesarias al inicio del mismo.

En los momentos actuales, después de dos siglos de relativa independencia política, pero no tan segura independencia económica, es necesario estudiar y revitalizar los elementos más valiosos del pensamiento independentista que se planteó junto a las reivindicaciones de justicia social y defensa de los derechos humanos la necesidad imperiosa de la integración latinoamericana.

PALABRAS CLAVES: pensamiento independentista latinoamericano, democracia, derechos humanos, justicia social.

\section{ABSTRACT:}

The struggle for independence of the colonies in general, i.e. both hemispheres and also in the Caribbean region must be appreciated in its real magnitude as a chapter in the fight to universally human rights, social justice and the construction of modernity. A propellant element of this fight were numerous uprisings of indigenous, slaves, peasants, etc., that occurred throughout the Americas before the independence process, whose superior expressions were Bolívar, San Martín, O’Higgins, Artigas, Hidalgo, Morelos, Martí, accompanied by thousands of Creoles, mestizos and blacks, Indian, etc. in the fight not only for political independence, but also for their rights and social justice. Independence processes in Latin America were forced to face in the new historical circumstances some requirements and demands of rights and social justice were not so obvious and necessary at the beginning of the same.

In the current, moments after two centuries of relative political independence, but not so secure economic independence, necessary study and revitalize the most valuable elements of independence thought raised to the claims of social justice and defence of human rights imperative for the Latin American integration.

KEY WORDS: Latin American independence thought, democracy, human rights, social justice.

Fecha de recepción febrero 17 de 2010

Fecha de aprobación: maYO 24 de 2010

\footnotetext{
* Académico titular de la Academia de Ciencias de Cuba. Doctor en Ciencias (Cuba) y Doctor en Filosofía (Leipzig). Profesor titular de la Cátedra de Pensamiento Latinoamericano de la Universidad Central de Las Villas, Santa Clara, Cuba.
} 
Son múltiples los espacios políticos, académicos y culturales en que el búho de Minerva, luego de contribuir al esclarecimiento conceptual de la noche de ignorancia y explotación de los sectores marginados del pueblo latinoamericano, le facilita el paso a nuevas aves cantoras de la mañana que con alegría anuncian sociedades más justas y dignificantes del hombre de estas tierras.

$\mathrm{E}$ 1 proceso de lucha por su independencia de las colonias americanas en general, es decir, en ambos hemisferios y también en la región de El Caribe debe ser apreciado en su real magnitud como un capítulo de la lucha a escala universal por los derechos humanos, la justicia social y la construcción de la modernidad, independientemente del hecho que la mayoría de los países liberados de sus respectivos yugos coloniales participasen en ese festín solo recogiendo migajas en el patio, como sugiriese Octavio Paz.

Es evidente que Estados Unidos de América y Canadá lograron de un modo diferente involucrarse de una manera más efectiva y beneficiosa al proceso promotor de dicha festividad. Algo distinta, pero no menos meritoria, fue la participación de los pueblos latinoamericanos en esa labor pues,

si entendemos la emancipación como un proceso de realización en libertad de la condición humana en
Nuestra América, vale entonces indagar sobre los avances que en ese sentido representaron hombres, mujeres y movimientos libertarios que a lo largo y ancho del continente fueron construyendo en conjunto la posibilidad de un mundo diferente. ${ }^{1}$

Aun cuando la modernidad en América Latina, más que pospuesta o retardada, resultó, a nuestro juicio malograda, ${ }^{2}$ no cabe la menor duda de que aun así, junto al logro de la independencia en la mayoría de los países del área, se alcanzaron avances significativos en el proceso de humanización del hombre latinoamericano, por cuanto el tema de la conquista de sus derechos y de su dignificación no fue simplemente una cuestión de eruditos intelectuales o de abogados, sino de revolucionarios que necesariamente tenían que operar en el campo de la política antes que en el del derecho, pues "no hay emancipación mientras no se enfrente y supere la alienación, lo que en últimas remite al campo y la acción política más que jurídica”’

1. Bohórouez, C. "Miranda y el bicentenario de las independencias" en Las independencias de América Latina. Génesis, proceso y significación actual. Caracas: Ministerio del Poder Popular para la Cultura. 2009, pág. 12.

2. Véase: Guadarrama, P. “La malograda modernidad latinoamericana” en Exégesis. Año 7 \# 20. Puerto Rico, 1994, págs. 13-18. Reproducido en Guadarrama, P. América Latina, marxismo y postmodernidad. Bogotá: Universidad InCCa de Colombia, 1994; Guadarrama, P. Humanismo, marxismo y postmodernidad. La Habana: Editorial Ciencias Sociales. 1998.

3. Mejía Quintana, O. "Alienación, derecho y democracia deliberativa. Contex to y potencialidades emancipatorias de la cultura política" en Problemas de la filosofía del derecho, la política y la argumentación jurídica. Ángel, J. Duarte, R. y Elías, P. Coordinadores. Bogotá: Universidad Libre. 2009, pág. 54. 
No es correcto ignorar, como elemento propulsor de los derechos humanos y la justicia social a escala universal, el papel de innumerables sublevaciones de indígenas, esclavos, campesinos, etc., que se produjeron en toda América antes del proceso independentista, como las sublevaciones de Tupac Amaru, Tupac Katari, Wilka, en el Alto Perú, los comuneros liderados por Galán en la Nueva Granada, las insurrecciones en la Sierra Madre Oriental en México, así como la permanente y ancestral lucha de mapuches, pijaos y otros pueblos originarios que no se sometieron al conquistador o se enfrentaron con las armas a su poder.

Del mismo modo fueron expresiones de tales luchas por la justicia social próceres de la independencia como Miranda, Bolívar, San Martín, O’Higgins, Artigas, Hidalgo, Morelos, Martí, entre otros, acompañados por miles de criollos, mestizos, negros, indios, en la lucha no solo por la independencia política sino también por sus derechos y por la justicia social.

Está claro que la problemática de los derechos humanos como una necesidad de la construcción social moderna surge de los cambios revolucionarios que le dan impulso definitivo a un nuevo modo de organizar y concebir la sociedad ${ }^{4}$.

El tema de la justicia social y los derechos humanos se convirtió en uno de los elementos vitales de las luchas independentistas y de los cambios revolucionarios que se fueron planteando distintos sujetos sociales que coadyuvaron de diferente forma a la realización de la vida republicana.
Llama la atención que algunos "molinos de viento" que recientemente cierto discurso postmodernista ha combatido junto a la modernidad, han sido las ideas de progreso y de sentido lineal de la historia, el poderío de la razón, de la ciencia, la técnica, la educación, la ilustración, el optimismo histórico respecto al perfeccionamiento y democratización del mundo, su secularización al dejar la religión en la esfera privada separada de la política, el reconocimiento del papel de los populares, por citar algunos, elementos todos que acompañan a cualquier proceso emancipatorio y desalienador del hombre. Sin embargo, si no se hubieran realizado aunque fuese parcialmente algunas de estas ideas, el mundo actual indudablemente tendría mucho que lamentar y tal vez ni siquiera hubieran podido desplegarse las concepciones posmodernistas.

El pensamiento ilustrado situó parte de estas ideas, especialmente la de progreso y sentido de la historia, en planos muy renovadores y distantes del tradicional teleologismo, sin embargo es cierto que algunas interpretaciones posteriores como las de Hegel, el positivismo y hasta unos cuantos "marxismos" en ocasiones recurrieron a especie de socorridos mesianismos laicos.

Junto a la idea de progreso emanada de la Ilustración y que inspiró el pensamiento independentista latinoamericano, se intentaron poner en crisis ya desde fines del siglo XX según el neoliberalismo y el postmodernismo otros conceptos colaterales tan significativos como el de humanismo, socialismo, democracia y de derechos humanos ${ }^{5}$.

4. Acosta, F. Universo de la política. Bogotá: Pedagogía para lo superior. 2004, pág. 168.

5. Véase: Guadarrama, P. "Los derechos humanos ante el conflicto modernidad y posmodernidad" en Nova et vetera. Revista de la Escuela Superior de Administración Pública. Bogotá: ESAP. I Semestre 2008, págs. 59-73. 
Tal vez la indiferencia política actual de amplios sectores populares en algunos países ante los procesos electorales puede ser una muestra de cansancio de la modernidad ante su propia ineficiencia o de lo que Giovanni Sartori llama "el agotamiento de los ideales" ${ }^{\prime \prime}$.

En los momentos presentes, después de dos siglos de relativa independencia política, pero no tan segura independencia económica, es necesario estudiar y revitalizar los elementos más valiosos del pensamiento independentista que se planteó, junto a las reivindicaciones de justicia social y defensa de los derechos humanos, la necesidad imperiosa de la integración latinoamericana.

La sociedad capitalista en sus etapas de afianzamiento y expansión en el orbe necesitaba de múltiples ingredientes no solo económicos, financieros y tecnológicos, sino una serie de móviles ideológicos y culturales que por un lado favoreciera la consolidación de una mentalidad de ciudadanos libres y, por otro, posibilitara en el plano de la sociedad política y la sociedad civil el logro de niveles superiores de justicia social y de derechos humanos, que superaran las imprescindibles demandas de autonomía o independencia.
Algunas de esas posturas se expresarían de modo sui generis en Latinoamérica antes, durante y después de las luchas independentistas, indicando que los problemas a resolver en esta parte del mundo cargaban con el lastre de más de tres siglos no solo de injusticia social, sino hasta de aniquilamiento físico de los pueblos originarios de estas tierras.

De tal manera que la lucha por la independencia no podía, en modo alguno, limitarse a un simple cambio en los protagonismos de las élites políticas de dirección, y de esto se percataron la mayor parte de los que impulsaron dicho proyecto. $\mathrm{Si}$ bien algunos de los participantes en el mismo se vieron limitados en sus pretensiones emancipadoras, reduciendo la cuestión de la toma del poder político a un problema de ofrecer nuevas oportunidades a las oligarquías criollas sin tomar en plena consideración que las mayorías de los sec-

6. "En última instancia, puede ser que la razón final de la crisis, sin mencionar la falta de cordura de la democracia liberal, sea que estamos mimados, dominados por las "necesidades corporales" y asustados". SARToRi, G. Teoría de la democracia. 2. Los problemas clásicos. Madrid: Alianza Universidad. 1988, pág. 591. 
tores populares, en primer lugar lógicamente los esclavos, cogestores decisivos en aquellas guerras independentistas estaban imbuidos por alcanzar no solo la independencia de la metrópoli colonial sino una sociedad más dignificadora de sus respectivos derechos y condiciones de vida.

Esto puede apreciarse en el caso de Colombia desde la última década del siglo XIX, cuando en 1794 se produce la conspiración criolla en la que se involucra a Francisco Antonio Zea y Luis de Rieux. Según Javier Ocampo:

En estos procesos de 1794 se enfrentaron las dos tendencias políticas, características de finales del siglo XVIII: los tradicionales, partidarios de la monarquía, la Iglesia, la tradición cristiana y el orden colonial, los modernistas, simpatizantes de las nuevas ideas modernas, impulsadas por la Ilustración, defensores de los derechos del hombre, las libertades, las ideas democráticas y del laicismo contra la religiosidad. ${ }^{7}$

A lo que habría que añadir la significación de la traducción y publicación, por Antonio Nariño, de la Declaración de Derechos del hombre y el ciudadano que dio lugar a que fuese procesado, especialmente, por su defensa del derecho de la soberanía popular.

Los paradogmas (falacias) de libertad, igualdad y fraternidad se pondrían en la probeta de ensayos para intentar demostrar su eficacia y validez una vez lograda la independencia.
Desde que se iniciaron los intercambios culturales entre los pueblos de la antigüedad han existido diversos grados y ritmos de universalización cultural, pero siempre cuando lo específico ha trascendido incrementando los niveles de dominio de los hombres sobre sus condiciones de existencia, ha habido cultura universal y libertad. Tales procesos se aceleraron con el ascenso histórico del capitalismo y han llegado a niveles de internacionalización de la vida contemporánea que resultan en ocasiones delirantes.

Pensar que la historia de la entrada de nuestra América a los tiempos modernos puede medirse temporalmente con el tiempo específico que reclama para todo sistema la teoría de la relatividad, puede resultar un ejercicio, más que fisicalista, pernicioso.

Es imposible desarticular la modernidad europea del proceso expansivo y colonizador sobre estas tierras americanas y otras del orbe, que simplemente participaron del show de la modernidad, pero desde la calle. Sin poder disfrutar de los deleites del buffet. Eso no significa de ningún modo que el acontecimiento no tuviera lugar, sólo sucedió que las invitaciones eran tan limitadas que incluso muchos inquilinos del centro, varios de los cuales son ahora víctimas de la xenofobia, tuvieron que compartir con sus vecinos periféricos la nostalgia.

América Latina, por otra parte, no puede seguir esperando que algún día el show se repita para 
disfrutarlo en toda su plenitud. Esa posibilidad no se ofrecerá jamás. Tampoco parece recomendable saltar de lleno hacia la presunta postmodernidad, teniendo pendiente tantas deudas con la modernidad.

Históricamente las potencias coloniales y neocoloniales han tratado de debilitar al máximo sus zonas de dominio bajo el presupuesto de la consigna imperial romana de divide y vencerás. Por esa misma razón los pueblos en lucha por su independencia y soberanía han visto en la unidad, la solidaridad por la justicia social y la integración política y económica la única posibilidad de enfrentarse a tan poderosas fuerzas.

Un ejemplo elocuente se muestra en el proceso independentista latinoamericano el cual hubiera sido absolutamente imposible si se hubiese desplegado de manera aislada y sin el apoyo solidario de unos pueblos con los otros, tal y como se llevó a cabo.

Los próceres de la independencia latinoamericana, forjados en el espíritu de la Ilustración y la pujante modernidad, estuvieron muy conscientes de que solo de una forma cohesionada y solidaria en la lucha no solo por la independencia política sino también por la justicia social era realizable aquella empresa. De la misma forma que en la actualidad los que se enfrentan a las nuevas potencias hegemónicas saben que sin integración resultará muy difícil y postergada la lucha por la dignificación de los pueblos latinoamericanos.

Del mismo modo que sin la integración de las fuerzas revolucionarias que protagonizaron las luchas por la independencia, sin tomar en consideración fronteras artificiales levantadas por los conquistadores y colonizadores para administrar mejor su poder no era posible la lucha, en la actualidad las nuevas fuerzas emancipadoras frente a los monopolios transnacionales propiciados por las políticas neoliberales en tiempos de globalización están obligadas a propiciar la integración latinoamericana en todos los planos posibles y a su fundamentación ideológica para lograr algún éxito.

Es sabido que la historia no se mueve por ideas, pero también sin ideas no se construye ni remodela la historia. De ahí que la intelectualidad latinoamericana tiene la misión de revitalizar los ideales integracionistas desarrollados por generaciones anteriores y a la vez gestar nuevas ideas-fuerza que contribuyan a servir de móvil paradigmático a las nuevas acciones sociales liberadoras.

El pensamiento latinoamericano de la integración fecundó en el último período de la época colonial como condición ideológica necesaria de fermentación de las ideas independentistas y de justicia social. Este pensamiento integracionista de los pueblos de esta región tenía antecedentes anteriores pero en verdad logró su mayor madurez a principios del XIX.

No cabe la menor duda de que la Ilustración latinoamericana desempeñó el papel de cimentadora de las transformaciones ideológicas y políticas que se exigían para resolver el proceso independentista, de reivindicación de los derechos humanos, justicia social e integrador de nuestros pueblos. Esto no es nada extraño, pues la Ilustración se caracterizó precisamente por ser un movimiento filosófico de marcada raigambre política y social. Ya se había apreciado en Francia y en otros países tanto de América Latina como del Asia, regiones 
en las cuales la Ilustración fructificó y no debe ser apreciada como mera extensión mimética del pensamiento europeo del mismo modo que no se puede considerar que las ideas democráticas y sobre derechos humanos son conquistas exclusivas de la cultura occidental ${ }^{8}$.

Es cierto que fue en Europa donde primero se manifestaron las exigencias transformadoras reclamadas por el expansivo capitalismo, pero en la medida en que sus redes fueron alcanzando otras regiones del orbe que se incorporaban a sus dominantes relaciones, las ideas ilustradas se hacían más necesarias, no como un simple proceso exógeno desde las potencias centrales hacia los países periféricos sino como una necesidad del propio desarrollo endógeno de estos últimos.

En todas partes pensadores de esta época fueron inquisidores del status quo existente, especialmente en cuanto a las crecientes desigualdades sociales. Se cuestionaron la validez del sistema político monárquico absolutista en la mayoría de los casos, o monárquico constitucional, o un poco más liberal en otros, pero en definitiva monárquicos. Era la expresión política de aquel sistema autárquico feudal que limitaba las pujantes relaciones burguesas de producción y distribución, que exigía la apertura a un mercado mundial más abierto y en el que las relaciones esclavistas aun cuando en un primer momento ensamblaban con el capitalismo expansivo, paulatinamente comenzaban a obstaculizarlas considerablemente.
La preocupación de los ilustrados latinoamericanos por revitalizar los estudios sobre los valores de las culturas precolombinas, como es el caso de Francisco Javier Clavijero con la azteca, es otra muestra de que no sólo constituían el preámbulo de un nuevo sujeto histórico de la cultura y la vida políticosocial latinoamericana, sino que se enorgullecían por lo general de autoconstituirse en objeto de la búsqueda científica y de la reflexión antropológica del nuevo Siglo de las Luces.

En América se fue creando una base de discusión teórica sobre lo que demandaban las relaciones burguesas para su despliegue omnilateral: 1) un desarrollo científicotécnico acelerado, 2) el fomento de la industria y de la capacidad creativa de las nuevas generaciones, 3) el enfrentamiento a una mera postura reproductiva y consumidora, 4) pero especialmente se reclamaría también conquistas políticas y jurídicas de ciudadanía, democracia, libertad, igualdad -al menos en el plano jurídicoderechos humanos y ante todo posibilidades para el logro de una mayor equidad y justicia social.

En definitiva los ilustrados latinoamericanos, como Eugenio de Santa Cruz y Espejo en Ecuador, Francisco José de Caldas en la Nueva Granada, y Félix Varela y José de la Luz y Caballero en Cuba, contribuyeron a la fermentación ideológica desalienadora que propiciaría a inicios del siglo XIX la emancipación política, como premisa indispensable para alcanzar niveles superiores de realización de un humanismo solidario y de integración de las culturas en estas tierras.

8. Véase Guadarrama, P. "Democracia y derechos humanos: ¿"Conquistas” exclusivas de la cultura occidental? “ en Nova et Vetera. Bogotá: Escuela Superior de Administración Pública. II Semestre 2009, págs. 79-96. 
Los ilustrados latinoamericanos, como Andrés Bello y Simón Rodríguez en Venezuela, o José Celestino Mutis y Antonio Nariño en la Nueva Granada, consideraban la educación como la vía fundamental para elevar a planos superiores el desarrollo económico en primer lugar, pero sobre todo las distintas esferas de la sociedad civil y de la política que permitieran una mejor participación del hombre en la elección de un destino común para los pueblos de la región, que concebían, necesariamente, debían integrarse en una sola comunidad política y económica.

El siglo XVIII había sido para los latinoamericanos el del despertar de cierta autoconciencia de identidad y culto al conocimiento. El saber se convirtió en una fuerza propulsora de aquella sociedad aun cuando se limitase a la esfera de las reformas civiles y políticas, en tanto que este no siempre pudiese traducirse en empresas técnicas o económicas de envergadura como en aquellos momentos se estaba llevando a cabo en Europa con la Revolución Industrial.

La Ilustración sirvió para que la intelectualidad de estas tierras tuviese mejores condiciones para incidir de alguna forma en la actitud de los gobiernos de los distintos virreinatos y lograr un rango de apertura en muchos órdenes de la vida social, que se incrementaría paulatinamente sin posibilidad de retorno al dogmatismo y enclaustramiento de los tiempos anteriores.

Una característica del pensamiento ilustrado latinoamericano consistió en que se manifiesta, principalmente al inicio, entre sacerdotes que cultivaban la filosofía. No a través de filósofos laicos como fundamentalmente predominó en Europa. Fueron sacerdotes los que en estas tierras pro-

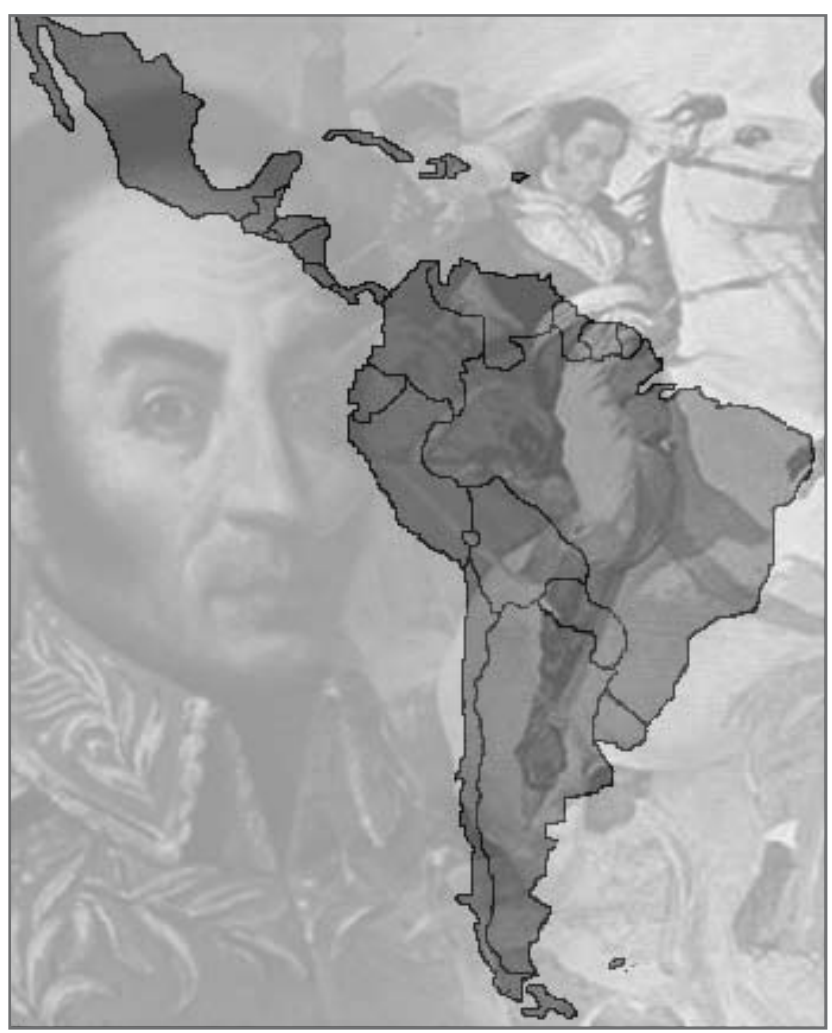

Los próceres de la independencia latinoamericana, forjados en el espíritu de la Ilustración y la pujante modernidad, estuvieron muy conscientes de que solo de una forma cohesionada y solidaria en la lucha no solo por la independencia política sino también por la justicia social era realizable aquella empresa. De la misma forma que en la actualidad los que se enfrentan a las nuevas potencias hegemónicas saben que sin integración resultará muy difícil y postergada la lucha por la dignificación de los pueblos latinoamericanos.

pugnaron ideas sensualistas y experimentalistas, sostuvieron tesis de profundo contenido humanista e incluso pusieron en duda determinadas prerrogativas de la Iglesia, al proponer avanzadas reformas sociales. 
No cabe la menor duda de que la Ilustración latinoamericana desempeñó el papel de cimentadora de las transformaciones ideológicas y políticas que se exigían para resolver el proceso independentista. Esto no es nada extraño, pues la Ilustración se caracterizó precisamente por ser un movimiento filosófico de marcada raigambre política y social ${ }^{9}$. Ya se había apreciado en Francia y en otros países, en los cuales la Ilustración no debe ser vista como meras extensiones de un fenómeno europeo.

En definitiva, todos los ilustrados latinoamericanos contribuyeron conscientemente o no a la fermentación ideológica desalienadora que propiciaría a inicios del siglo XIX la emancipación política, como premisa indispensable para alcanzar niveles superiores de la realización del humanismo y justicia social en estas tierras.

El pensamiento de la integración latinoamericana fue fermentado por las ideas ilustradas desde fines del siglo XVIII pero ante todo por la necesidad de la independencia política y justicia social. Tales ideas se articularon a la aspiración de que los pueblos latinoamericanos lograran una alta misión en la historia universal a diferencia de lo planteado por Hegel, sin embargo estas posturas se distanciaban del nacionalismo y en su lugar promovían un espíritu de solidaridad con los pueblos en lucha por su independencia.

Para el logro de tales objetivos los ilustrados latinoamericanos apreciaban la educación como la vía fundamental para elevar a planos superiores el desarrollo económico en primer lugar, pero sobre todo las distintas esferas de la sociedad civil y de la política que permitieran una mejor participación del hombre en la elección de su destino y en la lucha por sus derechos fundamentales. En ese sentido Antonio Nariño sería uno de esos ilustrados que enalteció el papel de la educación ${ }^{10}$ como derecho humano inalienable y factor desalienador.

La educación era concebida como el método más apropiado para que las recientes generaciones se formasen en nuevos valores que dejasen atrás las arbitrariedades del medievo aún latentes en América. Las clásicas consignas de libertad, igualdad y fraternidad, que resonaron en todos los rincones donde el pensamiento de la Ilustración arraigó, encontraban en las reformas en la educación una de sus principales vías de realización. Cualquier elemento enajenante que contribuyese a establecer obstáculos entre los hombres era criticado.

9. "La filosofía ilustrada es eminentemente política, un trabajo colectivo de la idea, una práctica social en sentido radical, incluso con horarios y lugares fijados, sin preocuparles la paternidad -ni la propiedad- de las ideas. En los salones se produciría dialécticamente (en diálogo y oposición); luego, cualquiera retomaba el discurso, lo escenificaba y, en fin, lo editaba, con frecuencia anónimo y retocado sin "escrúpulos" por el editor. Nunca ha habido una producción más social de las ideas". Bermudo Ávila, J. y otros. El pensamiento filosófico y político en la Ilustración francesa. Santiago de Compostela: Universidad de Santiago de Compostela.1992, pág. 36.

10. "Se tiene por degenerado al hombre natural; y se aplaude al filósofo virtuoso, porque acercándose a su primitivo estado, se contenta con el necesario posible, y desprecia las riquezas, el lujo, la disipación, esas comodidades tan decantadas de la vida social. Es menester confesar que el verdadero estado del hombre no conoce medio, y que si el primitivo y natural ya apenas se conoce, debe por la reflexión acercarse cuanto sea posible en medio de la sociedad, lo que en este estado sólo se podrá conseguir con la educación”. NARIÑo, A. “Sobre la educación” en La ilustración en Colombia. Bogotá: El Búho. 1996, pág. 118. 
El siglo XVIII fue para los latinoamericanos el del despertar de la conciencia sabia. El saber se convirtió en una fuerza propulsora de aquella sociedad, aun cuando se limitase a la esfera de las reformas civiles y políticas, en tanto que no pudiese siempre traducirse en empresas técnicas o económicas de envergadura como en aquellos momentos se estaba llevando a cabo en Europa, con la revolución industrial.

La Ilustración sirvió para que la intelectualidad de estas tierras tuviese mejores condiciones para incidir, de alguna forma, en la actitud de los gobiernos de los distintos virreinatos y lograr un rango de apertura en muchos órdenes de la vida social. Esto obstaculizaría paulatinamente la posibilidad de retorno al dogmatismo y enclaustramiento de los tiempos anteriores.

Algo a lo que también los ilustrados latinoamericanos le prestaron atención en su misión humanista y desalienadora fue al combate contra las supersticiones y el oscurantismo reinante en la época. En tal dirección, en Argentina, Fernández de Agüero, en su condición de sacerdote, jugó un papel positivo al someter a crítico juicio estas y otras formas de enajenación como las que devienen de los poderes políticos.

La Ilustración latinoamericana no se caracterizó desde un inicio por su radicalismo sino por su reformismo ${ }^{11}$, pero el propio proceso político independentista del cual ella era un preludio necesario, la impulsó a asumir ideas y proyectos de mayor envergadura que desbordaban los límites del pensamiento reformista.

En el pensamiento ilustrado latinoamericano se manifestaron casi todas las corrientes de pensamiento filosófico y teológico que proliferaron de distinto modo en Europa. Sin embargo, hubo problemas específicos como el de la condición humana y los derechos de los aborígenes de estas tierras que fueron retomados y reivindicados por los humanistas del XVIII, a raíz de las implicaciones ideológicas que tal tipo de discriminación traía aparejadas no sólo para aquellos, sino para todos los nativos americanos, incluyendo a los criollos. La escolástica sufrió un serio golpe con el advenimiento del humanismo ilustrado y fue debilitándose paulatinamente a pesar del apoyo institucional con que contaba por parte de la Iglesia y en especial por su imbricación con las necesidades legitimadoras de la dominación de las metrópolis.

El espíritu renacentista pujante que impulsaba ideas de profundo contenido humanista se hizo sentir definitivamente en el siglo XVIII, indicando los grados de autenticidad creciente que alcanzaría cada vez más la reflexión filosófica en América Latina.

El humanismo en el pensamiento latinoamericano durante la época colonial fue incrementando sus niveles de radicalización, lo que ha llevado a Arturo Andrés Roig a considerar que hubo una primera etapa de humanismo paternalista, entre

11. "La mayor parte del pensamiento ilustrado iberoamericano aparece en sus primeras etapas como eco del europeo y, por la misma razón, portador del espíritu reformista e innovador de la versión española”. Chiaramonte, J. Pensamiento de la ilustración. Caracas: Biblioteca Ayacucho. 1979, pág. XVIII. 
mediados del siglo XVI y primeras décadas del XVII, propio de los sacerdotes que no solo protegieron a los indígenas sino que reconocieron su alteridad; un humanismo ambiguo, en la América andina, al aparecer un nuevo sujeto histórico que comienza a asumir roles protagónicos: la clase terrateniente criolla, y un humanismo emergente, ya propio de la Ilustración, que preparaba los cambios exigidos ${ }^{12}$.

Sin este nuevo sujeto histórico era imposible construir una nueva cultura en estas tierras, y el pensamiento filosófico auténtico no podía germinar plenamente si no existían las manos adecuadas que lo cultivasen como sucedió a partir de ese momento.

Es cierto que no en todas partes de esta América el espíritu de la modernidad y sus logros como el de la democracia, compartimentación de poderes, igualdad, libertad, secularización, tolerancia, derechos humanos, etc., encontraron oídos adecuadamente receptivos, pero el reconocimiento de la validez universal de tales conquistas de la civilización obligó a que hasta los regímenes dictatoriales se viesen obligados a utilizar tales pieles de cordero. Este hecho, de algún modo u otro, tendría una incidencia positiva en el proceso de humanización del hombre latinoamericano.

Ya en el pensamiento del precursor de la independencia latinoamericana, Francisco de Miranda, se aprecia la intención de que la victoria conduzca a conquistar condiciones dignas de vida de los pueblos originarios de estas tierras cuando señalaba:

Ciudadanos, es preciso derribar esta monstruosa tiranía: es preciso que los verdaderos acreedores entren en sus derechos usurpados: es preciso que las riendas de la autoridad pública vuelvan a las manos de los habitantes y nativos del país, a quienes una fuerza extranjera se las ha arrebatado ${ }^{13}$.

Es indudable que en Miranda como en otros próceres prevalece el criterio reivindicativo de los derechos de todos los sectores populares, en especial de los pueblos indígenas así como de los negros esclavos y el logro de la igualdad como una conquista necesaria incluso para la población humilde mestiza y blanca. Sin embargo, esto no significaría que los prejuicios aristocráticos arrastrados durante múltiples generaciones hubieran desaparecido de la noche a la mañana en él ${ }^{14}$, aun cuando estuviese consciente del valor

12. RoIg, A. A. Humanismo en la segunda mitad del siglo XVIII, t. I. Quito: Banco Central de Ecuador.1984, pág. 25.

13. Miranda, F. "Proclama a los pueblos del continente colombiano. Alias Hispano-América" en Ideas en torno de Latinoamérica. Coordinación de Humanidades de la UNAM. México. D.F.: UDUAL. 1986, pág. 352.

14. "Más profunda todavía fue la experiencia de la igualdad de derechos políticos y sociales para todos los ciudadanos de condición libre. Si la segregación racial respecto a los negros y a los indios había sido y continuaba siendo más marcada en los Estados Unidos que en las posesiones españolas, la democracia republicana, por el contrario, había elevado a toda la población blanca a las mismas condiciones de igualdad independientemente de las diferencias en su nivel social o económico. A Miranda le costó mucho aceptar esa igualdad. A pesar de su admiración por los principios democráticos, los prejuicios de clase estaban tan profundamente arraigados en su ser, que no llegaba a aceptar que, por ejemplo, su sirviente, igualmente blanco, se sentara a comer a su lado en la misma mesa”. Bohórouez, C. Francisco de Miranda. Precursor de la independencia de la América Latina. Caracas: Universidad Católica Andrés Bello-Universidad del Zulia. 2001, pág. 101-102. 
y el significado de alcanzar tales conquistas de justicia social.

Por supuesto que todos estos precursores de la unidad americana, como el hondureño José Cecilio Valle quien denominaba a América como su patria $^{15}$, pensaron siempre en los derechos y en la integración de aquellos pueblos producto de la mezcla de los aborígenes, los negros importados por la esclavitud y la colonización hispano lusitana. No consideraban regularmente que dicha unidad se diera con los pueblos de Norteamérica. Más bien, por el contrario, observaron con recelo las políticas expansionistas de los gobiernos de los Estados Unidos de América que hasta el nombre de americanos acapararon de manera exclusiva para su pueblo.

Por tal motivo comenzaron a surgir denominaciones diferenciadoras de las de los pueblos y la cultura de Norteamérica, como las de Hispanoamérica, Iberoamérica, América Latina o Latinoamérica durante el siglo XIX, cada una con su consecuente connotación ideológica ${ }^{16}$, así como el de Indoamérica de más reciente creación en el siglo XX. Tales términos eran expresión de búsqueda de elementos comunes de identificación cultural, pero también de alternativas políticas y económicas de un destino común que facilitara soluciones satisfactorias de desarrollo en un mundo de nuevas formas de dominación.

Es notorio que la indagación de elementos de identificación cultural entre los pueblos latinoa-
El ideario social bolivariano, inspirado en lo mejor del pensamiento ilustrado europeo, se planteaba ir más allá de la guerra independentista para lograr el gobierno más favorecedor posible de seguridad, derechos y justicia social. "El sistema de gobierno más perfecto es aquel que produce la mayor suma de felicidad posible, mayor suma de seguridad social y mayor suma de estabilidad política”

mericanos se incrementó considerablemente luego de alcanzada la independencia política, como vía de resistencia ideológica a los nuevos poderes imperiales neocolonizadores provenientes de Europa y Estados Unidos. Si por una parte algunos sectores de la aristocracia criolla se dejaban seducir por la xenofilia cultural, un grupo destacado de intelectuales y políticos de profunda raigambre patriótica reivindicaron los valores de la cultura y los pueblos latinoamericanos como necesidad de consolidar la independencia política.

Uno de los precursores de esa especie de "Independencia cultural de Hispanoamérica” fue, el también maestro de Bolívar, el venezolano Andrés Bello y por tal motivo ha sido denominado como el "libertador intelectual de América".

\footnotetext{
15. OQuelli, R. Introducción a José del Valle. Antología. Tegucigalpa: Universidad Nacional Autónoma de Honduras. Editorial Universitaria. 1981, págs. 28-29.

16. Véase “¿Pan-latinismo, pan-hispanismo, pan-americanismo, solidaridad?” en Bosch García, C. El descubrimiento y la integración iberoamericana. México: UNAM. 1991, págs. 267-276.
} 
El americanismo de Bello, como plantea Leopoldo Zea ${ }^{17}$, no solo se manifestó en las descripciones del paisaje de estos países sino en la idea de patria como fuerza espiritual en la que se funden sentimientos de identificación. Su labor educativa e intelectual al servicio diplomático de Venezuela, Colombia y Chile estimuló la integración de los pueblos de esta región, como se manifestó en 1844 cuando se discutían las bases de una "Confederación de Hispanoamérica”.

En ocasiones las posturas integracionistas de numerosos líderes independentistas han quedado opacadas al lado de la estatura del Libertador Simón Bolívar. Pero resulta injusto desconocerlas ya que en ocasiones algunas de ellas tuvieron mucho impacto y repercusión en su época, como en el caso de Francisco de Miranda, José de San Martín y Bernardo O’Higgins. Este último tomó iniciativas diplomáticas muy definidas, independientemente de que no llegaran a tener mayor repercusión, por lograr la integración americana partiendo primero de la unión de Chile y Argentina y posteriormente, el 6 de mayo de 1818, expidiendo un Manifiesto convocando a un congreso "llamado a instituir una gran confederación de los pueblos americanos" $^{18}$.
San Martín aspiraba a la unión del Río de la Plata, Chile y Perú ${ }^{19}$. Bernardo Monteagudo, su principal consejero, elaboró y publicó el Ensayo sobre la necesidad de una federación general de estados hispanoamericanos ${ }^{20}$ y muchos otros, como el chileno Juan Egaña en 1825, ${ }^{21}$ también abogaron por la urgencia de lograr la integración latinoamericana.

Miranda, O’Higgins, San Martín y Bolívar fueron ante todo representantes de la vanguardia de aquellos genuinos hombres de su época que comprendieron que la lucha por la independencia estaba inexorablemente vinculada al logro de la integración americana, los derechos humanos y la justicia social. Y una época de ilustración reclamaba hombres ilustrados e ilustradores, que supieran asimilar las ideas más avanzadas del momento, pero que no se contentaran con la acomodaticia postura de ser iluminados por el pensamiento europeo. Hombres que supieran encontrar en la circunstancia histórica específica de nuestra América, en la cual se desenvolvían, el escenario adecuado para enriquecer su visión del mundo.

La tarea emancipadora de los próceres de la independencia y en especial de Bolívar no se limitó a

17. "Andrés Bello, como muchos de sus contemporáneos, en especial sus grandes coterráneos, Miranda, Bolívar, Rodríguez y Sucre, se sentía parte del gran continente descubierto por Colón y actuó como tal”. ZEA, L. "El americanismo de Bello" en Andrés Bello. Valoración múltiple. Al cuidado de Manuel Gayol Mecías. La Habana: Casa de las Américas. 1989, pág. 726.

18. Barrios, M. Historia diplomática de Chile 1541-1938. Barcelona: Ariel. 1970, pág. 82.

19. Guerra Vilaboy, S. El dilema de la independencia. Las luchas sociales en la emancipación americana. (1790-1826). Bogotá: Universidad Central. 2000, pág. 368.

20. Frank, W. Nacimiento de un mundo. Ensayos. La Habana, 1967, pág. 405.

21. "Es forzoso repeler la fuerza por la fuerza, es forzoso que la denominada Santa Alianza de los príncipes agresores se oponga la sagrada confederación de los pueblos ofendidos”. Ramos, J. Historia de la Nación Latinoamericana. t. I. A. Peña Lillo, Editor. Buenos Aires, 1975, pág. 284. 
derrumbar los poderes políticos que subyugaban al hombre latinoamericano, sino también otras fuerzas alienantes como la ignorancia, que han enajenado al hombre cuando este no posee los instrumentos adecuados para liberarse de ellas. Su labor no era solo lograr la independencia sino consolidar la indispensable integración y justicia social de los pueblos latinoamericanos.

Del mismo modo las ideas de igualdad no necesariamente significaban que estuvieran imbuidas por el democratismo o el pensamiento de Rousseau, que se hizo presente de algún modo en Bolívar.

En algunos casos, como se aprecia en San Martín, la lucha por la independencia aunque constituiría un paso de avance en el proceso emancipador para los sectores más afectados en la escala social como era el de los esclavos ${ }^{22}$, esto no implicaba en modo alguno eliminar o atenuar las diferencias clasistas sino propiciar que éstas no se convirtieran en obstáculo para el mejoramiento de todos los sectores sociales a la vez, lo que no los distanciaba de múltiples utopías abstractas que germinaron en el pensamiento ilustrado.

Creo -sostenía San Martín- que es necesario que las constituciones que se den a los pueblos estén en armonía con su grado de instrucción, educación, hábito y género de vida, y que no se le deben dar las mejores leyes, pero sí las más apropiadas a su carácter, manteniendo las barreras que separan las diferentes clases de la sociedad, para conservar la preponderancia de la clase instruida y que tiene que perder. ${ }^{23}$

Tal preocupación por no afectar la situación de la clase económicamente dominante una vez lograda la independencia se observa en su Proclama de $1818^{24}$. Este conflicto entre los objetivos que se planteaban algunos sectores económicamente favorecidos con el logro de la independencia y sus posibles consecuencias democratizadoras de la riqueza o favorecedoras de tendencias que propiciaran una mayor igualdad social fue una constante que estuvo latente desde el inicio de las guerras de independencia y se mantuvo hasta tal punto que favoreció las actitudes incluso antagónicas que se observaron en distintos sectores copartícipes en aquellas luchas.

Algo más radical fue la proyección social de Bolívar, que contaba en su formación con la influencia de su maestro Simón Rodríguez a quien con razón se le considera entre los precursores del socialismo utópico en estas tierras americanas. ${ }^{25}$

22. "San Martín emitió toda una serie de disposiciones antifeudales al ocupar la presidencia peruana: suprimió la mita, abolió los tributos y servicios personales sufridos por los campesinos indígenas, extrañó al arzobispo de Lima, reformó el sistema de comercio, proclamó la libertad de los vientres, emancipó a todos los esclavos que tomasen las armas a favor de la independencia, suprimió los azotes en las escuelas, estableció la libertad de imprenta, prohibió aplicar tormentos en los procesos judiciales, estableció la inviolabilidad de domicilio”. Prieto, Alberto. Próceres latinoamericanos. Editorial Gente Nueva. 1981, pág. 70.

23. Citado por LiÉvano Aguirre, I. Bolívar. La Habana: Editorial Ciencias Sociales. 2005, pág. 216.

24. San Martín, J. "Proclama a los limeños y habitantes de todo el Perú" en Ideas en torno de Latinoamérica. T. II. Coordinación de Humanidades de la UNAM. México. D.F.: UDUAL, 1986, pág. 1263.

25. "El proyecto socialista de Rodríguez propone una república, habitada por los sujetos antes excluidos, sujetos reproducidos en la educación social satisfechos en cuanto a sus necesidades básicas, y por ello capaces de construir una nueva sociedad en tierra americana”. Ciriza, A. "Simón Rodríguez: un socialista utópico americano” en Itinerarios socialistas en América Latina. Estela Fernández Nadal (Compiladora). Córdoba: Alción Editora. 2001, pág. 31. 
El ideario social bolivariano, inspirado en lo mejor del pensamiento ilustrado europeo, se planteaba ir más allá de la guerra independentista para lograr el gobierno más favorecedor posible de seguridad, derechos y justicia social. "El sistema de gobierno más perfecto es aquel que produce la mayor suma de felicidad posible, mayor suma de seguridad social y mayor suma de estabilidad política”26.

Bolívar sabía muy bien que no bastaba con la independencia si no se resolvían los problemas de la libertad de los esclavos y, en general, de la población que sobrevivía en condiciones humillantes por lo que si no se superaba esa degradante situación a la larga se producirían explosiones sociales, ya que las revoluciones, como ha planteado Fidel Castro, son como los volcanes, no es necesario que nadie las encienda, explotan solas cuando se acumulan durante un tiempo sus fuerzas generatrices reprimidas. Por eso el Libertador, en 1826, preocupado al respecto le escribía a Páez: “¿Quién contendrá a las clases oprimidas? La esclavitud romperá el fuego: cada color querrá el dominio." ${ }^{27}$

Y dado que el problema del derecho a la posesión de la tierra, junto al de la esclavitud, era crucial para la solución de los problemas principales de la población marginada por siglos de explotación, su adecuado reparto fue una de las medidas de mayor significación para lograr un mayor grado de justicia social. Desde 1817 repartió tierras entre los que le habían acompañado en las guerras independentistas. En 1824 ordenó en Trujillo y en 1825 en el Cuzco después de la batalla de Ayacucho, que se les entregara a todos los indígenas de cualquier sexo o edad una porción de tierra que sería mayor en caso de que fuesen estériles y privadas de riego, lo cual evidencia su sentido de la equidad.

Sin embargo, no obstante las buenas intenciones tanto de Bolívar como de otros líderes del proceso independentista latinoamericano de repartir la tierra de manera individual entre los indígenas, con el objetivo de incorporarlos lo antes posible a las nuevas formas de producción, distribución y consumo que el capitalismo por doquier demandaba, estas medidas no tomaban en adecuada consideración que las formas tradicionales y ancestrales de propiedad y producción de la tierra de los pueblos originarios eran colectivas y que un cambio acelerado de formas de propiedad podía producir, como de hecho produjo, resultados contraproducentes pues los terratenientes pudieron desplegar posteriormente un latifundismo fagositósico engullendo poco a poco a cada uno de aquellos propietarios aislados ${ }^{28}$. Otra hubiera sido su suerte si se hubiese distribuido la tierra

26. Bolívar, S. "Discurso de Angostura. 15 de febrero de 1819” en Miguel Acosta Saignes. Introducción a Simón Bolívar. México: Editorial Siglo XXI. 1983, pág. 97.

27. “Carta de Bolívar a Páez, 4 de agosto de 1826” en John Lynch. Las revoluciones hispanoamericanas (1808-1826). Barcelona: Ariel, 1980, pág. 34.

28. "Privar a los indígenas de la seguridad modesta de la ayuda mutua dentro de sus comunidades y declararlos propietarios individuales significa exponerlos a una explotación más directa con la perspectiva de despojarlos totalmente". Thiemer-Sachse, U. "Simón Bolívar y los indígenas del Nuevo Mundo” en Interpretaciones y ensayos marxistas acerca de Simón Bolívar. Akademie Verlag, Berlin, 1985, pág. 76. 
José María Samper, contrario a la colonización española e imbuido

por las ideas positivistas, atacó el desprecio a los indígenas, mestizos y criollos que prevalecía aun después de la independencia. Así como el fanatismo y otros males sociales que debían ser erradicados por medio de la educación y el desarrollo de instituciones civiles modernas.

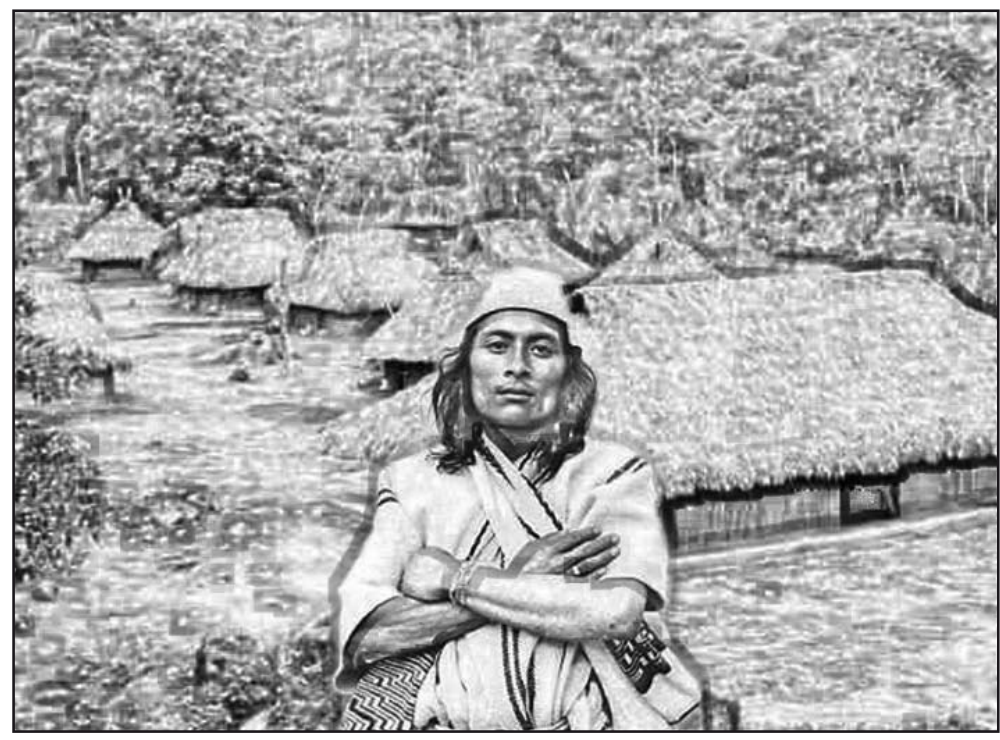

en forma comunitaria y se hubiesen mantenido las formas precapitalistas de producción, al menos de manera inmediata.

Bolívar, según plantea José Consuegra Higgins, superó a las concepciones fisiocráticas prevalecientes en la mayoría de los economistas coloniales pues

Para Bolívar el desarrollo social dependía del trabajo y el saber. Juicio, por cierto, más completo que el de los economistas europeos mencionados. Porque en verdad, el saber, que supone la instrucción científica, técnica y literaria facilita el rendimiento óptimo del esfuerzo humano aplicado a la producción de la riqueza ${ }^{29}$.

Convencido del poder del saber, por primera vez en América instituyó Bolívar la educación obligatoria a todos los jóvenes mayores de cuatro años y menores de catorce. Una de las tareas principales que se propuso una vez lograda la independencia fue el fomento de la educación y que ésta llegara a los sectores sociales menos favorecidos en la escala social, pues estaba convencido de que por esta vía podía atenuarse en algo tanta desigualdad social y racial a fin de lograr mayores niveles de justicia.

Bolívar no llegó a escribir obras propiamente filosóficas, pero en todo su epistolario, en numerosos documentos, proclamas, etc., se aprecian innumerables reflexiones de profundo carácter filosófico respecto a los más diversos problemas, especialmente en cuanto a los derechos humanos y la justicia social. En ellas se aprecia tanto su concepción particular sobre el lugar de la filosofía en el saber humano, como la recepción creadora que hay en él de las ideas de la Ilustración y en general su ideario profundamente humanista.

El pensamiento ilustrado, y en especial la filosofía, que lo sustanciaba, sin dudas, constituía para Bolívar un insustituible instrumento del cual la humanidad ya no podría prescindir jamás en su 
progresiva marcha desalienadora. Esto se aprecia claramente en su célebre discurso de Angostura, de 1819, en el que sostenía:

ya todos los seres que piensan han aprendido cuáles son los derechos del hombre y cuáles sus deberes; en qué consiste la excelencia de los gobiernos y en qué consisten sus vicios. Todos saben apreciar el valor intrínseco de las teorías especulativas de los filósofos y legisladores modernos ${ }^{30}$.

De tal modo, como pudo apreciarse anteriormente, a la vez que criticaba aquellos sistemas filosóficos, que alejados de la realidad en lugar de ayudar a dominarla enajenaban mucho más al hombre, sabía otorgar el valor necesario a las teorías filosóficas que contribuían al enriquecimiento de la condición y la plenitud humana, como prevalecía en la Ilustración.

Su confianza en el hombre y su capacidad de autoperfeccionarse se revela a través de sus criterios sobre el papel de los pueblos y sus derechos como gestores de sus propios destinos, y en la función de la violencia revolucionaria como partera de la historia. Esto queda plasmado cuando sostiene que: "El pueblo que ama su independencia, por fin la logra”"1.

Con ese propósito sostiene la necesidad de desplegar la violencia revolucionaria como expresión superior de la actividad humana en el plano social, para exterminar la no menos activa violencia reaccionaria, que tiene como fin último doblegar a los pueblos e infundirles la falsa creencia de su incapacidad para transformar sus circunstancias sociales.
Bolívar le otorga a la subjetividad una fuerza extraordinaria, pues sitúa en la exclusiva actividad humana la esperanza potencial de toda liberación. La libertad, a su juicio, no se logra ni se mantiene fácilmente y hay que intentar alcanzarla siempre, aun cuando no se avizore su inmediata obtención. Pues, para él, la libertad es consustancial al hombre por naturaleza propia y cuando está ausente se debe a que éste permite que se le enajene de ella y no emprende su reconquista y enriquecimiento.

Observaréis muchos sistemas de manejar hombres -decía en 1819-, mas todos para oprimirlos; y si la costumbre de mirar el género humano conducido por pastores de pueblos no disminuye el horror de tan chocante espectáculo, nos pasmaríamos al ver nuestra dócil especie pacer sobre la superficie del globo como viles rebaños destinados a alimentar a sus crueles conductores. La naturaleza a la verdad nos dota al nacer del incentivo de la libertad; mas sea pereza, sea propensión inherente a la humanidad, lo cierto es que ella reposa tranquila aunque ligada con las trabas que le imponen ${ }^{32}$.

Esto significa que concibe la libertad como un producto complejo, elaborado a partir de componentes naturales y sociales, entre los cuales se destacan la sabiduría y la gestión humanas como insustituibles intermediarios en su consecución. Apoyándose en Rousseau, Bolívar consideraba la libertad como "un alimento suculento, pero de difícil digestión. Nuestros débiles conciudadanos -sostenía- tendrán que enrobustecer su espíritu

30. Acosta SaIgnes, M. Introducción a Simón Bolivar. México: Siglo XXI, 1983, pág. 99.

31. Bolívar, S. Obras completas. La Habana: Editorial Lex, 1947, T. I: 160.

32. Bolívar, S. "Discurso de Angostura” en Obras completas. La Habana: Editorial Lex. 1947, T. I., pág. 91. 
mucho antes que logren digerir el saludable nutritivo de la libertad"33. En correspondencia con tales criterios el Libertador estaba convencido de que si el pueblo no se preparaba a través de la educación y el cultivo del saber en todas sus dimensiones, no podría jamás disfrutar del poder de la libertad.

Los poderes enajenantes, de distinto orden y magnitud, se entrenaban permanentemente en buscar opciones que posibilitasen que masas humanas menesterosas mantuvieran el status quo de dominación. A su juicio:

Por el engaño se nos ha dominado más que por la fuerza, y por el vicio se nos ha degradado más bien que por la superstición. La esclavitud es la hija de las tinieblas; un pueblo ignorante es instrumento ciego de su propia destrucción: la ambición, la intriga, abusan de la credulidad y de la inexperiencia de hombres ajenos de todo conocimiento político, económico o civil ${ }^{34}$.

En tal empeño las luces emanadas por la filosofía de la ilustración debían borrar toda sombra alienante.

El realismo optimista en su visión del pueblo se plasma a través del convencimiento de que éste debe ser el sujeto principal de su propia liberación y de su propio futuro. Esto hace que en el pensamiento latinoamericano de su época, Bolívar constituya uno de los mejores exponentes de la recepción creadora del humanismo, la defensa de los derechos humanos y el optimismo histórico, de los cuales está impregnada la Ilustración, que trasciende a planos superiores por su compromiso orgánico en la praxis liberadora y alcanza dimensiones de humanismo práctico y justicia social.

Al Bolívar plantear que: "causas individuales pueden producir resultados generales, sobre todo en las revoluciones" ${ }^{\$ 5}$, dejaba a su vez sentado su criterio sobre la aceleración y mayor viabilidad de la acción individual, en momentos tan decisivos de la historia como esos cuando el papel de los sectores populares se multiplica y alcanza dimensiones colosales, pero a la vez las personalidades encuentran condiciones más propicias para destacarse. Es ese el momento en que afloran con ímpetu extraordinario y desempeñan un papel protagónico en el desarrollo social.

No se puede liberar del todo a Bolívar de una cierta dosis de utopía en sus proyectos políticos, como se aprecia en su idea de la unidad de todos los pueblos latinoamericanos. Aún hoy en día se mantiene como un ideal concreto y necesario frente a la peligrosa doctrina abstracta del panamericanismo que él combatió desde sus orígenes y que hoy se levanta nuevamente amenazante. En definitiva, su latinoamericanismo, como el de José Martí, no era infundado, ni mucho menos se trataba de algo absolutamente imposible de acrisolar. En todo revolucionario siempre hay necesariamente dosis indispensables de idealismo, de altruismo. Y Bolívar no podía ser una excepción, cuando se trata del revolucionario e internacionalista más grande de todos los tiempos en nuestra América.

\footnotetext{
33. Idem, pág. 173.

34. Idem, pág. 126.

35. Idem, pág. 173.
} 
Pero cuando Bolívar luchaba por realizar ideas que para muchos de sus contemporáneos eran absolutamente utópicas, como la liberación de los esclavos, por considerar que: "la infracción de todas las leyes es la esclavitud" ${ }^{\text {"6 }}$ o cuando reclamaba la dignificación de los pueblos indígenas, no lo hacía inspirado en el humanismo abstracto al que nos han acostumbrado innumerables discursos de politicastros, sino en las conquistas más altas del pensamiento de la Ilustración sobre la igualdad y la libertad humanas, que tenían en Rousseau a uno de sus mayores exponentes.

Su agudeza le permitió nutrirse muy selectivamente de las ideas de este pensador y de otros de la Ilustración al respecto ${ }^{37}$, pero más que la utilización erudita o la retórica refinada, que no estaban tampoco ausentes en su depurada oratoria, su misión consistió en utilizar aquel instrumental de ideas atemperándolas a este "pequeño género humano” y a la vez ex trayendo las experiencias y enseñanzas que sus años de lucha le habían permitido elaborar, aportando criterios al pensamiento ilustrado latinoamericano ${ }^{38}$.

Plena conciencia tenía el Libertador de la trascendencia de las conquistas a alcanzar, pues no se trataba simplemente de echar de estas tierras a un conquistador o evitar la subrepticia llegada de otro disfrazado, como se aprestaba en esos tiempos tempranos el naciente imperio estadounidense del Norte, sino que la tarea era mucho más difícil pues la cuestión era desarraigar los poderes endógenos que querían mantener en la servidumbre y la esclavitud a grandes sectores de la población, cuando las nuevas fuerzas impulsoras del capitalismo, esto es, la naciente burguesía, era aún muy débil.

No debe ignorarse lo señalado por Mariátegui cuando apuntaba que: "Enfocado sobre el plano de la historia mundial, la independencia sudame-

36. Idem, pág. 126.

37. "Que los hombres nacen todos con derechos iguales a los bienes de la sociedad, está sancionado por la pluralidad de los sabios; como también lo está, que todos los hombres nacen igualmente aptos a la obtención de todos los rangos; pues todos deben practicar la virtud y no todos la practican; todos deben ser valerosos y todos no lo son, todos deben poseer talentos, y todos no los poseen. De aquí viene la distinción efectiva que se observa entre los individuos de la sociedad más liberalmente establecida. Si el principio de la igualdad política es igualmente reconocido, no los hombres desiguales, en genio, temperamento, fuerzas y caracteres. Las leyes corrigen esta diferencia porque colocan al individuo en la sociedad para que la educación, la industria, las artes, los servicios, las virtudes, le den una igualdad ficticia, propiamente llamada política y social”. Idem, pág. 96.

38. "Bolívar como pensador y hombre de acción -observa Leopoldo Zea- ha captado esa peculiar situación de pueblos como los de esta América en donde se entrelaza la lucha de clases con la lucha anticolonial, relacionada esta con la situación racial. Sabe Bolívar que no es suficiente romper políticamente con el imperio español, este rompimiento ha de abarcar el sistema mismo del que es expresión tal imperio: emancipación de los esclavos, reparto de la tierra y participación de todas las clases en la marcha de las nuevas naciones. Algo que sus caudillos no comprendieron aprestándose, simplemente, a ocupar el vacío de poder dejado por el colonialismo. Para ellos fue un simple cambio de señores, expulsados los colonizadores criollos y mestizos se aprestaban a tomar su lugar manteniendo la servidumbre sobre los grupos que ya lo sufrían. En esa incomprensión, nacida del egoísmo y de los intereses, ve el propio Bolívar el origen del fracaso de su utopía liberadora. La emancipación de estos pueblos, no solo ha de ser horizontal, de la colonia frente al imperio, sino vertical, interna, la de un grupo social frente a otro". ZEA, Leopoldo. "Bolívar y la liberación nacional” en Bolívar y el mundo de los libertadores. México: UnAM, 1993, pág. 25. 
ricana se presenta decidida por las necesidades de desarrollo de la civilización occidental o, mejor dicho, capitalistas". ${ }^{99}$ Y dado que ya existía una embrionaria burguesía en estas tierras sudamericanas, resultaba fácil el contagio con las ideas revolucionarias provenientes de la Revolución Francesa y la Constitución norteamericana. De manera que el proceso independentista debe ser apreciado también, pero no exclusivamente, como una vía necesaria de incorporación de los pueblos latinoamericanos al desarrollo pleno del capitalismo mundial independientemente que haya resultado en un ensayo en cierta medida frustrado, al menos en cuanto a la satisfacción de las demandas populares se refiere. Sin embargo, no caben dudas, que la tarea principal a resolver era el logro pleno de la independencia respecto a la metrópoli ${ }^{40} \mathrm{y}$ las demás tareas sociales y económicas, como la lucha por el establecimiento de los derechos humanos y mayor justicia social, estarían subordinadas a la misma. También en el pensamiento y la praxis revolucionaria de los próceres mexicanos Hidalgo y Morelos fue evidente su postura de no limitar la lucha a la conquista de la independencia sino de hacerla trascender al logro de una mayor justicia social y conquista de derechos humanos para los sectores populares.
Hidalgo, quien en 1810 redactó tres decretos aboliendo la esclavitud y favoreciendo a los pueblos indígenas, decretó

se entreguen a los referidos naturales las tierras para su cultivo; sin que, para lo sucesivo, puedan arrendarse pues es mi voluntad que su goce sea únicamente de los naturales en sus respectivos pueblos. ${ }^{41}$

Siguiendo su ejemplo, Morelos en 1811 ordenó que debían entregarse "las tierras a los pueblos para su cultivo, sin que puedan arrendarse, pues su goce ha de ser de los naturales en los respectivos pueblos" ${ }^{42}$, por lo que Agustín Churruca con razón plantea que:

Como fruto de sus observaciones y juicios, Morelos no se limitó a criticar la sociedad colonial sino que intentó redimir al pueblo de la explotación, o sea, lograr tanto el desarrollo económico del país como establecer la justicia social. De ahí su política agraria concreta y práctica, dictada al contacto de la realidad y en el terreno mismo de los hechos, de ahí también el régimen de impuestos que elaboró y las diversas medidas económicas que efectuó en el territorio reconquistado. ${ }^{43}$

La reivindicación de los derechos de las capas más humildes de la población estuvo concebida por los

39. Mariátegui, J. C. Siete ensayos de interpretación de la realidad peruana. La Habana: Casa de Las Américas, 1975, pág. 15.

40. “... si bien -observa Leonardo Paso- en el mundo de comienzos del siglo XIX, la lucha principal estaba entablada entre el feudalismo y la burguesía, con sus características en cada país de Europa, y elementos de la misma se trasladan a América, ello no quiere decir que la contradicción principal entre España y América asuma exacta y claramente dicho carácter”. PAso, L. De la colonia a la independencia nacional. Buenos Aires: Editorial Futuro, 1963, pág. 211.

41. De la Torre Villar, E. La independencia de México. México: FCE, 1980, T. I: 394.

42. Morelos, J. M. Circular. Techan 18 de abril de 1811.

43. Churruca, A. "Fuentes del pensamiento de Morelos" en Repaso de la independencia. Compilación y presentación de Carlos Herrerón Peredo. El Colegio de Michoacán, Morelia, 1985, pág. 138. 
próceres de esa gesta emancipatoria como parte no solo del proceso de independencia sino también de unidad e integración latinoamericana.

Finalmente -planteaba acertadamente Ricaurte Soler- es en nombre de la nación americana que una democracia radical agraria, desde México al Plata, conjuga la independencia con la redistribución de la tierra y el ataque al latifundio. ${ }^{44}$

Este hecho se aprecia en Gervasio Artigas quien, no obstante haber sido uno de los más poderosos ganaderos, sin embargo su identificación con la población humilde y en especial con las tribus charrúas, hizo que en nombre de los verdaderos americanos en la Banda Oriental del Uruguay se propusiese en el Reglamento Provisorio del año 1915 desarrollar una reforma agraria y confiscar las tierras de los realistas. Según su concepción combatía a los latifundios que pertenecían a "los males europeos y peores americanos" ${ }^{25}$.

En otro momento, en las denominadas Instrucciones del año XIII, a fin de participar en la Asamblea General Constituyente de las Provincias Unidas del Río de la Plata demandaba una serie de medidas propiciatorias del triunfo de la modernidad y la justicia social, entre ellas, además de la independencia total de España, la división de poderes del Estado, la libertad civil y religiosa, la libertad de pensamiento y un gobierno republicano que asegurase tales derechos.

Por su parte, Bernardo O'Higgins también ha quedado en la historia no solo como el héroe militar independentista sino por haberse enfrentado a aquellas instituciones retardatarias que tanto en Chile como en Perú debían ser eliminadas para propiciar mayores grados de justicia social, derechos humanos y construcción de la necesaria modernidad. Esa actitud se plasmó al abolir la esclavitud y tratar de eliminar el poder de la Iglesia Católica y de la nobleza criolla, por lo que prohibió sus títulos y confiscó los bienes de los enemigos de la independencia, entre otras medidas.

Todas y cada una de estas disposiciones se caracterizaban por su extraordinario impacto socioeconómico, por lo que dejaban a las claras que la lucha no era sólo contra un enajenante poder foráneo, sino también contra las injustas relaciones precapitalistas de producción imperantes en aquella sociedad latinoamericana. De manera que muchos de los que dirigieron la lucha en diversas regiones del continente se vieron precisados por las circunstancias a tomar partido respecto a la dirección que debían seguir los acontecimientos e incluso sacrificar posiciones económicas personales, actitud esta que cuando encontró una consecuente renuncia a los intereses privados en aras de los sociales y colectivos resulta mucho más meritoria.

Es conocido también que algunos de los combatientes por la independencia no estuvieron de acuerdo con muchas de las medidas de raigambre popular y social que emprendían los más relevantes conductores de aquel majestuoso suceso, por lo que se produjeron innumerables enfrentamientos, traiciones, abandonos, etc., que evidenciaban que la lucha por la independencia solamente sería consumada si iba unida a una mayor justicia social.

\footnotetext{
44. Soler, R. "Bolívar y la cuestión nacional americana" en Bolívar y el mundo de los libertadores. México: UNAM, 1993, pág. 44. 45. Romero, J. L. (Prólogo y selección) Pensamiento político de la emancipación. Caracas: Biblioteca Ayacucho, 1977, pág. 23.
} 


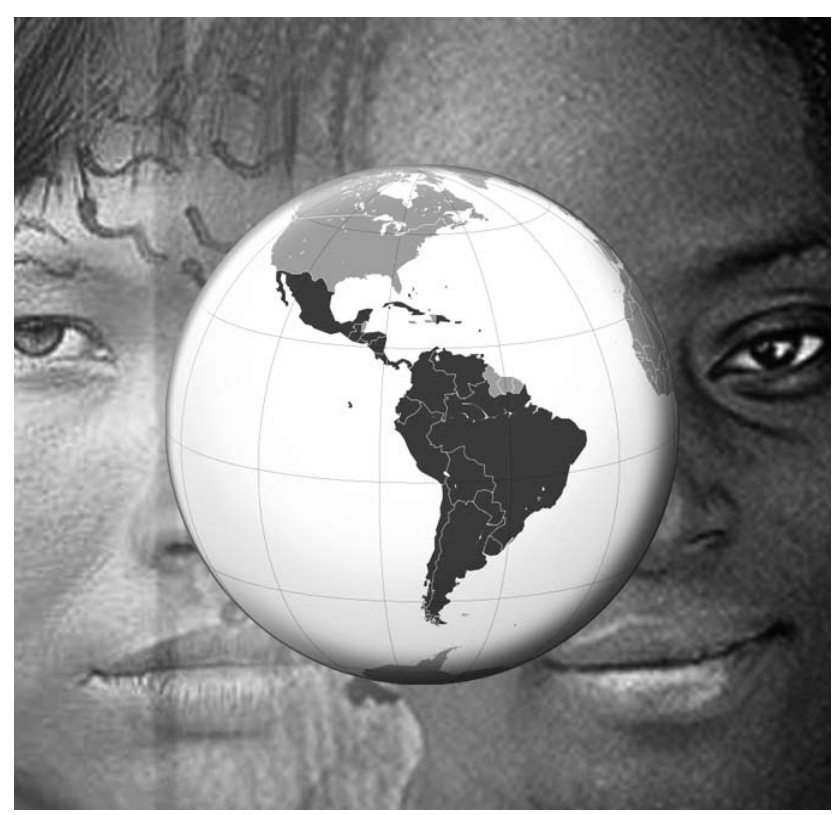

El radicalismo de Mariano Moreno ha llevado a Alberto Prieto a plantear que:

Su programa de acción, inspirado en criterios jacobinos, contemplaba expropiar a unos seis mil potentados, nacionalizar los yacimientos mineros, realizar una profunda reforma agraria y controlar a los comerciantes porteños, mediante una estricta reglamentación estatal de intercambio mercantil con el extranjero ${ }^{46}$.

Y tales ideas no se quedaron en meras intenciones pues en el Alto Perú las victoriosas tropas de Juan José Castelli se dieron a la tarea de ponerlas en práctica al proscribir múltiples instituciones feudales que doblegaban a la población indígena, eliminaron el pago de tributos, distribuyeron las grandes haciendas entre sus peones y proclama-
En los días actuales en que el protagonismo de la población originaria de estas tierras en algunos de los países latinoamericanos se levanta, no solo ya para protestar, como ha sido hasta ahora lo común, sino para dirigir, cooperar, sugerir, aconsejar y decidir, pareciera que comenzara a completarse el empeño parcialmente fracasado de justicia social emprendido por los próceres de la independencia. ron la indispensable igualdad de todos para que aquellas guerras no concluyeran con un simple cambio de administración política y se pasasen por alto las ancestrales demandas populares.

Por la misma época, en Ecuador, Vicente Rocafuerte, primero como representante de México en Inglaterra, defendió la idea de la unidad hispanoamericana de las ex colonias españolas y la necesidad de una comunidad constitucional de naciones hispánicas ${ }^{47}$. Luego como presidente de su país planteó que el progreso de los pueblos hispanoamericanos no se lograría solo por la vía económica, sino con reformas sociales y emancipación mental a través de la educación y la adopción de la Constitución Federal Americana ${ }^{48}$ apropiada a las condiciones específicas de estos pueblos.

46. Prieto, A. Próceres americanos. La Habana: Editorial Gente Nueva, 1986, pág. 33.

47. OCAmpo López, J. La integración latinoamericana. Bogotá: Editorial El Búho, 1991, pág. 254.

48. Rocafuerte, V. "Ensayo político" en Pensamiento ilustrado ecuatoriano. Estudio introductorio y selección de Carlos Paladines. Quito: Banco Central de Ecuador, 1981, pág. 574. 
En ese mismo país, Juan Montalvo defendió la emancipación mental y cultural de América Latina. En su trabajo Ojeada sobre América criticó las nuevas formas de violencia que se desplegaron después del proceso independentista y que atentaban contra el progreso, la justicia social y la unidad de nuestros pueblos.

Uno de los precursores del pensamiento socialista utópico en América Latina, Esteban Echeverría, sugería en Argentina la necesaria emancipación mental de los pueblos de Hispanoamérica a fin de liberarlos de los rezagos coloniales y lograr mayores niveles de justicia social ${ }^{49}$. En su Dogma socialista sostenía que ya eran independientes, pero todavía no eran libres y consideraba a la educación como la vía para poder establecer la democracia en estos países.

Por su parte, Juan Bautista Alberdi, también en ese país, estimuló la inmigración europea y el desarrollo técnico e industrial similar a Norteamérica junto a la necesidad de un impulso a la educación y de un pensamiento filosófico propio de profunda raigambre política.
En tanto Sarmiento, no obstante sus concepciones racistas y subestimadoras de los pueblos indígenas, llegó a proponer la creación de unos Estados Unidos de América del Sur para que emulara con los del Norte sobre sus mismas bases de progreso industrial, derechos humanos y desarrollo democrático liberal.

El chileno Francisco Bilbao, uno de los propugnadores iniciales del término América Latina, no solo condenó a los Estados Unidos por su intervención en México y Centroamérica sino que planteó la creación de una confederación de países para enfrentarse a los Estados Unidos y su política expansionista. Propuso la creación de una única ciudadanía americana, como derecho de todos los habitantes de estas tierras y un congreso federal con poderes legislativos para todos los países ${ }^{50}$.

También el chileno José Victoriano Lastarria desde las posiciones de un positivismo comteano, dentro de las formas sui generis que adoptó en este continente, ${ }^{51}$ planteó la necesidad de una emancipación mental y cultural de América por medio de la educación. Defendió la autenticidad

49. Véase: Guadarrama, P. Marxismo y antimarxismo en América Latina. Bogotá: UnInCCA, 199 1, La Habana-México: Editora Política-El caballito, 1994 .

50. "Nuestros padres tuvieron un alma y una palabra para crear naciones; tengamos esa alma para formar la nación americana, la confederación de las repúblicas del sur, que puede llegar a ser el acontecimiento del siglo y quizás el hecho precursor inmediato de la era definitiva de la humanidad. Álcese una voz cuyos acentos convoquen a los hombres de los cuatro vientos para que vengan a revestir la ciudadanía americana. Que del foro grandioso del continente unido, salga una voz. Adelante, adelante en la tierra poblada, surcada, elaborada, adelante con el corazón ensanchado para servir de albergue a los proscritos e inmigrantes, con la inteligencia para arrancar los tesoros del oro inagotable, depositados por Dios en las entrañas de los pueblos libres, adelante con la voluntad para que se vea en fin la religión del heroísmo, vencedora de la fatalidad, vencedora de los hechos y vencedora de las victorias de los malvados". Bilbao, F. "Iniciativa de la América. Ideas de un Congreso Federal de las Repúblicas” en Latinoamérica. México: Cuadernos UNAM, n. 3, pág. 26.

51. Véase: Guadarrama, P. Positivismo en América Latina. Bogotá: UnAD, 2000; Positivismo y antipositivismo en América Latina. La Habana: Editorial Ciencias Sociales, 2004. 
de la cultura y el cultivo del pensamiento latinoamericano como una de las vías para lograr una emancipación plena.

La idea de una integración de los países latinoamericanos tomó cada vez mayor fuerza en la segunda mitad del siglo XIX, como se aprecia en quien se considera uno de quienes utilizaron tempranamente también el término de Latinoamérica, el colombiano José María Torres Caicedo ${ }^{52}$. En 1865 publicó su obra Unión Latinoamericana en la que proponía un sistema liberal para el comercio; una convención de correos, libre de gravámenes para los periódicos, la abolición de los pasaportes, unidad de principios consulares y de comercio como elementos de los derechos de un "ciudadano latinoamericano”. Además propuso que ningún país latinoamericano puede ceder parte alguna de su territorio, ni apelar al protectorado de ninguna potencia mundial.

Por su parte José María Samper, contrario a la colonización española e imbuido por las ideas positivistas, atacó el desprecio a los indígenas, mestizos y criollos que prevalecía aun después de la independencia. Así como el fanatismo y otros males sociales que debían ser erradicados por medio de la educación y el desarrollo de instituciones civiles modernas.

Para Rafael Núñez el principal error de la colonización española no fue haber simplemente suplantado con la suya la dominación indígena, sino el no haber comprendido la necesidad de reformarse y ponerse a la altura de los nuevos tiempos. Del mismo modo las recientes repúblicas debían crecerse ante las nuevas circunstancias del progreso y el desarrollo industrial. Planteaba una renovación del pensamiento, por eso consideraba que incluso a "la obra de los libertadores tampoco podía aplicarse el criterio de los tiempos actuales". El proceso civilizatorio era permanente y reclamaba unidad y consenso de los pueblos.

En el caso de México, José María Luis Mora consideró que la educación pública era indispensable para los nuevos estados nacionales pues a través de ella se aseguraba la libertad y el orden, así como la emancipación mental mediante una educación laica. Esas mismas ideas impulsaron a Benito Juárez en su reforma, apoyado por el pensamiento de Gabino Barreda y la generación positivista.

Como puede apreciarse, varios de los más significativos representantes de la intelectualidad latinoamericana del siglo XIX impulsaron la idea de lograr a través del fomento de la educación y la cultura una mayor unidad de los pueblos de América Latina y la conquista de sus derechos.

Es evidente que las formas ideológicas prevalecientes en los inicios de las luchas independentistas latinoamericanas a principios del siglo XIX, recién influidas por la ideas de la Ilustración y las revoluciones burguesas del XVII y el XVIII en Europa y Norteamérica, lógicamente tendrían muy arraigadas las manifestaciones propias del humanismo abstracto típico de ese tipo de transformaciones, donde los sectores populares se ve-

52. "Desde 1851 empezamos a dar a la América española el calificativo de latina; y esta inocente práctica nos trajo el anatema de varios diarios de Puerto Rico y de Madrid.” Torres Caicedo, J. M. Mis ideas y mis principios. París, 1875. T.I. pág. 151. 
rían de algún modo representados por una pujante burguesía frente a los poderes feudales.

Algo diferente fue la situación cuando Cuba y Puerto Rico extendieron sus luchas independentistas a fines del siglo XIX. Para entonces el capitalismo había desplegado un proceso de maduración y definición especialmente con el fracaso de algunos procesos revolucionarios, el restablecimiento por una parte de fuerzas conservadoras y, lo que es más importante, ya se habían ido decantando las antagónicas contradicciones entre la burguesía y los sectores populares, especialmente la clase obrera que ya reclamaba sus derechos.

La experiencia de la Comuna de París había anunciado al mundo que nuevas fuerzas sociales se aprestaban a tomar el poder y que las ideas socialistas y anarquistas habían dejado de ser una mera ilusión filantrópica, intentando tomar cuerpo en la gestación de un nuevo tipo de sociedad.

De manera que los procesos independentistas de América Latina obligatoriamente se verían obligados a afrontar en las nuevas circunstancias históricas algunos requerimientos y demandas de derechos y justicia social que no eran tan evidentes y necesarias al inicio del mismo.

Esta es la razón por la cual el pensamiento independentista de José Martí tendría necesariamente que articularse no solo con demandas pendientes de justicia social como la abolición de la esclavitud, sino también con nuevas exigencias frente a la esclavizada situación de obreros y campesinos con el despliegue del capitalismo y a las nacientes relaciones de dominación imperialistas que conducían a emprender una segunda independencia. Para el prócer cubano: "La manera de celebrar la independencia no es, a mi juicio, engañarse sobre su significación, sino completarla”. ${ }^{53}$

Una de las tareas más urgentes que Martí se planteaba para el logro de mayores grados de justicia social era elevar el nivel educativo y cultural en general del pueblo, pues en primer lugar consideraba que: "No hay igualdad social posible sin igualdad de cultura" ${ }^{44}$ Por eso a partir del criterio de que "ser culto es el único modo de ser libres”, ${ }^{55}$ se planteó junto a la emancipación política emprender de inmediato la lucha por elevar al máximo posible el nivel educativo de los sectores populares, ya que consideraba que:

53. Martí, J. “Carta a Valero Pujo. El progreso. Guatemala. 27 de noviembre de 1877. Obras completas. La Habana: Editorial Ciencias Sociales, 1975. Epistolario. T.I. pág. 98.

54. Martí, J. "El plato de lentejas". Patria. Nueva York, 5 de enero de 1894. Obras completas. La Habana: Editorial Ciencias Sociales, 1975. T. III, pág. 28.

55. Martí, J. "Maestros ambulantes” La América. Nueva York, mayo 1884. Obras completas. La Habana: Editorial Ciencias Sociales, 1975, T. VIII, pág. 289.

56. Martí, J. "La exposición de materiales de ferrocarril de Chicago" La América. Nueva York, septiembre de 1883. Obras completas. La Habana: Editorial Ciencias Sociales, 1975, T. VIII, pág. 352. 
No hay nada más práctico que una buena teoría, sostenía con razón Einstein, y el deber de un intelectual auténtico que se identifique con las luchas independentistas en estos tiempos de su bicentenario -cuanto se hace más necesario que nunca contribuir a completar la segunda independencia y coadyuvar a las luchas sociales por mejorar la justicia social y las condiciones de vida de los sectores más humildes de estos pueblos-, es ser un buen intelectual.

"Hasta que los obreros no sean hombres cultos no serán felices” ${ }^{56}$.

A su juicio, "De todos los problemas que pasan hoy por capitales, sólo lo es uno: y de tan tremendo modo que todo tiempo y celo fueran pocos para conjurarlo: la ignorancia de las clases que tienen de su lado la justicia”. ${ }^{57}$

Según el pensador cubano: "De la justicia no tienen nada que temer los pueblos, sino los que se resisten a ejercerla" ${ }^{58}$. Esto significa que para él la verdadera justicia siempre estaría de parte de los humildes, de los sectores explotados y marginados, independientemente de que otra cosa haya sido hasta el presente la mayor parte de la historia del mundo y solo muy recientemente nuevos ensayos de utopías concretas de democratización social, -no exclusivamente en el plano político-, y de socialismo ${ }^{59}$, cuando algunos pensaban que ya desaparecerían de la faz de la tierra después de la caída del Muro de Berlín y que parecen estar destinados a contribuir en la conquista de la dignidad de los pueblos de Nuestra América.

La sensibilidad ética y política de Martí, que lo impulsó siempre a echar su suerte "con los pobres de la tierra" ${ }^{60}$, lo condujo a establecer una ecuación permanente entre pobreza e injusticia ${ }^{61}$ por lo que la justicia social y los derechos humanos

57. Martí, J. Prólogo de Martí a Cuentos de hoy y de mañana. De Rafael Castro Palomino. Nueva York, octubre de 1883. Obras completas. La Habana; Editorial Ciencias Sociales, 1975, T. V, pág. 101.

58. Martí, J. Carta al editor de The New York Herald. Guantánamo, 2 de mayo de 1895. Epistolario. Obras completas. La Habana: Editorial Ciencias Sociales, 1975, Tomo V, pág. 212.

59. Véase: Guadarrama, P. “Democracia, liberación y socialismo: sus relaciones” en Conceptos y fenómenos fundamentales de nuestro tiempo. Coordinador Pablo González Casanova. México: UNAM, 2009.

60. "Con los pobres de la tierras/quiero yo mi suerte echar/ el arroyo de la sierra/ me complace más que el mar". MARTí, J. "Versos sencillos”. 1891. Obras completas. La Habana: Editorial Ciencias Sociales, 1975, Tomo XVI, pág. 67.

61. "Mientras haya un pobre, a menos que no sea un perezoso o un vicioso, hay una injusticia”. Martí, J. "México en los Estados Unidos”. El Partido Liberal. México, 1887. Obras completas. La Habana: Editorial Ciencias Sociales, 1975, Tomo XI, pág. 109. 
solo se alcanzarían en el mundo dignificando la vida del pobre y, en el caso de América, tal relación estaba orgánicamente vinculada a la situación del indio.

El conocimiento de la situación de la población aborigen de América, al llegar a México y Guatemala le hizo expresar: "Es bello que los indígenas descalzos repitan las ideas en que se consagran sus derechos". ${ }^{62}$ Tomó conciencia Martí de un elemento esencial para que el proceso de la emancipación latinoamericana llegase a su plenitud, esto es, la decisiva participación del indio en todos los procesos sociales dirigidos al logro de una mayor justicia social. Por eso planteaba la disyuntiva: "O se hace andar al indio, o su peso impedirá la marcha" ${ }^{63}$. Estaba tan convencido que reiteraba: "Y hasta que no se haga andar al indio, no comenzará a andar bien la América" ${ }^{64}$.

En los días actuales en que el protagonismo de la población originaria de estas tierras en algunos de los países latinoamericanos se levanta, no solo ya para protestar, como ha sido hasta ahora lo común, sino para dirigir, cooperar, sugerir, aconsejar y decidir, pareciera que comenzara a completarse el empeño parcialmente fracasado de justicia social emprendido por los próceres de la independencia.
Son múltiples los espacios políticos, académicos y culturales en que el búho de Minerva, luego de contribuir al esclarecimiento conceptual de la noche de ignorancia y explotación de los sectores marginados del pueblo latinoamericano, le facilita el paso a nuevas aves cantoras de la mañana que con alegría anuncian sociedades más justas y dignificantes del hombre de estas tierras.

Es en estas nuevas circunstancias que se hace más necesario develar el compromiso orgánico de los profesionales, intelectuales, científicos, técnicos, artistas, entre otros, $-\mathrm{y}$ no solo líderes políticos o sociales, como se acostumbra-, identificados con los sectores populares para que contribuyan al esclarecimiento teórico de las nuevas circunstancias, pues pareciera que el mundo se ha transformado significativamente en los últimos tiempos, especialmente en el ámbito latinoamericano, en la última década del pasado siglo XX y en los primeros años del presente siglo XXI, y se hace cada vez más necesario volver a interpretarlo.

No hay nada más práctico que una buena teoría, sostenía con razón Einstein, y el deber de un intelectual auténtico que se identifique con las luchas independentistas en estos tiempos de su bicentenario -cuanto se hace más necesario que nunca contribuir a completar la segunda inde-

62. Martí, J. Escenas mexicanas. Revista Universal. México, 7 de mayo 1885. Obras completas. La Habana: Editorial Ciencias Sociales, 1975, Tomo VI, pág. 197.

63. Martí, J. “Arte aborigen”. La América. Nueva York, enero de 1884. Obras completas. La Habana: Editorial Ciencias Sociales, 1975, Tomo VIII, pág. 329.

64. Martí, J. "Autores americanos aborígenes”. Nueva York, abril de 1884. Obras completas. La Habana: Editorial Ciencias Sociales, 1975, Tomo VIII, pág. 33. 
pendencia y coadyuvar a las luchas sociales por mejorar la justicia social y las condiciones de vida de los sectores más humildes de estos pueblos-, es ser un buen intelectual.

De ese modo, unos desde el arte o la política, del mismo modo que otros desde el surco o la fábrica y algunos desde la escuela y la vida académica, es posible coadyuvar de manera distinta, pero igualmente imprescindible, a que el ideario de justicia social, respeto por los derechos humanos y el humanismo práctico de los próceres de la independencia y de muchos otros pensadores latinoamericanos, ${ }^{65}$ aun cuando sea con gran retraso y ante nuevos obstáculos, pueda efectivamente realizarse la necesaria integración latinoamericana y caribeña, que recientemente ha dado un paso trascendental con la creación en la Cumbre de Cancún de esta Comunidad de países.

En estos tiempos, no solo de rememorar, sino de revitalizar las luchas independentistas por la justicia social, los derechos humanos y la integración de nuestros pueblos, resulta muy pertinente recordar las sabias palabras de Don Quijote al no menos sabio Sancho Panza: "Los perros ladran, luego cabalgamos". ऍ

65. Véase: Guadarrama, P. Pensamiento filosófico latinoamericano: Humanismo vs. Alienación. Caracas: Editorial El Perro y la Rana, Ministerio de Cultura, República Bolivariana de Venezuela, Tomo I, II y III, 2008. 